- gene and select pig stocks free of it.

Having the full genome should also help investigators to breed out susceptibility to porcine reproductive and respiratory syndrome (PRRS), a viral disease costing the US pig industry US\$600 million per year. The PRRS Host Genetics Consortium, a network of US research groups, has identified a region on one chromosome that affects levels of virus in the blood during infection ${ }^{5}$. Archibald, who works on PRRS, says that the high-quality genome sequence should help investigators zero in on the genes responsible.

But the pig genome is not just about applications. Lead co-author Martien Groenen, a genome researcher from Wageningen University in the Netherlands, has resequenced the genomes of scores of different strains of wild and domestic pigs, and used the information to show that the pig was domesticated independently in Asia and Europe. He has also started to work out which genes were involved in the selection of desired traits - such as a longer spine to give more bacon - on different continents. "It's curiosity-driven research, but it may also help animal breeders in the future," he says..

1. Groenen, M. A. M. et al. Nature 491, 393-398 (2012).

2. Rogers, C. S. et al. Science 321, 1837-1841 (2008),

3. Renner, S. et al. Diabetes 59, 1228-1238 (2010).

4. Fujii J. et al. Science 253, 448-451 (1991).

5. Boddicker, N. et al. J. Anim. Sci. 90, 1733-1746 (2012).

BUSINESS

\title{
Investment relief for biotech sector
}

\section{Public markets provide cash injection for struggling field.}

\section{BY HEIDI LEDFORD}

$\mathrm{R}$ obert Forrester gets a little giddy when he talks about the day his company went public. The otherwise understated chief operating officer of Verastem, a small biotechnology company developing drugs to target cancer stem cells, chuckles and bounces in his chair as he recounts key strategic decisions along the way to the company's initial public offering (IPO) on 26 January, which raised US\$55 million.

Until recently, Verastem's IPO would have stood little chance. Few biotech companies have braved an IPO in the years since the global recession hit, and those that did often took a beating in the public markets. Venture capitalists began to pull out of the sector. Colleagues scoffed when Forrester told them that Verastem, a young company in Cambridge, Massachusetts, with no clinical data was going public. "Many people said, 'you've got to be kidding," he recalls.

But the IPO drought may be ending. This year has seen 12 biotech IPOs, and others are in the pipeline. So far, this has pumped some $\$ 800$ million into the sector, according to Renaissance Capital, an IPO-research company based in Greenwich, Connecticut. And biotech stocks are doing well - the NASDAQ Biotech Index has outperformed the NASDAQ Composite Index for the past 20 months (see 'Bullish on biotech'). "If this trend holds, it could be great news for the sector," says Josh Lerner, who studies venture capital at Harvard Business School in Boston, Massachusetts.

Restoring access to the public markets particularly for young companies that have few fund-raising options left - can give companies the capital they need to expand research programmes, hire more researchers or even just survive. It can also grant them access to 'generalist' investors who do not specialize in health care. "Public investors who may have been out of biotechnology for the past couple of years have started to move back in," says James Healy, a general partner at venture-capital firm Sofinnova Ventures in Menlo Park, California.

Observers credit several factors for the rising investor confidence in biotech. Large pharmaceutical firms eager to restock drug pipelines are gobbling up smaller firms at high prices. Biotechnology companies have celebrated several high-profile successes in the past 18 months, with the US Food and Drug Administration approving groundbreaking drugs such as vemurafenib, a genetically tailored drug for advanced melanoma whose prowess in knocking out tumours is matched by its jaw-dropping price tag - more than

\section{BULLISH ON BIOTECH}

An index fund of biotech companies is outperforming the NASDAQ composite index.

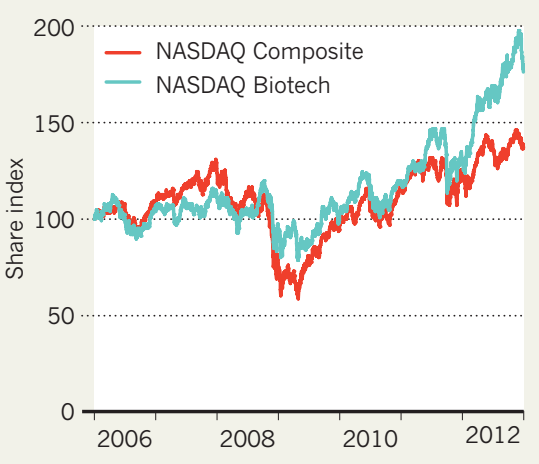

$\$ 50,000$ for six months of treatment.

Investors may also be drawn to the sector because of the poor performance of other industries, which are suffering more directly from the sluggish US economy, says Eric Schmidt, an analyst at investment bank Cowen and Company in New York. "Biotech earnings tend to grow independently of the economy, unlike electronics or consumer products," says Schmidt. "Everybody needs medicine."

The wave of public investment could help to offset the dearth of venture capital. A survey released last year by the National Venture Capital Association, headquartered in Arlington, Virginia, showed that nearly $40 \%$ of venture capitalists had decreased their investment in biotech during the previous three years, put off by the long timelines and high risks of drug development. Several prominent health-care funds have closed altogether. "Biotech is a money-eating machine," Lerner says. "The need for capital is so large, and given what's happened to venture capital, having alternatives is important."

Nowhere is that need greater than in young companies, the riskiest of all biotech investments, which have been among the hardest hit by the drop in venture funding. Verastem's IPO money advanced the company's business plan by two years; it should begin phase II trials of its leading compound by mid-2013, Forrester says.

But IPOs are not necessarily the answer for all struggling biotech ventures, cautions Brian Atwood, a managing director of Versant Ventures, a venture-capital firm in Menlo Park. He notes that many of the companies that pulled off IPO triumphs this year are unusual in some respect. Kythera Biopharmaceuticals of Calabasas, California, for example, is particularly appealing to investors because patients will have to pay out of their own pockets for its leading product $-\mathrm{a}$ fat-fighting injection designed to shrink double chins - rather than relying on health insurance and its accompanying cost controls. And Verastem's Forrester can barely utter a sentence without referencing the company's executives and scientific advisory board: a who's who of Boston's biomedical glitterati. Healy agrees: "It's a higher-quality set of companies that have recently gone public compared with those that may have gone public five years ago." - 